Jurnal Kajian Bimbingan dan Konseling

Vol. 1, No. 1, 2016, hlm. 1-6

Tersedia Online di http://journal.um.ac.id/index.php/bk

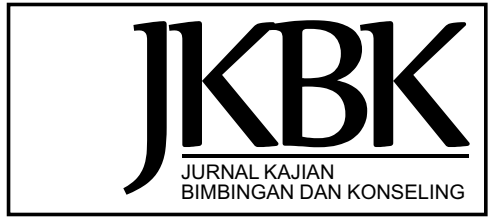

\title{
EFEKTIVITAS TEKNIK RELAKSASI DALAM KONSELING KELOMPOK BEHAVIORAL UNTUK MENURUNKAN STRES BELAJAR SISWA SMA
}

\author{
Istiana Nurcahyani, Lutfi Fauzan \\ Bimbingan dan Konseling-Fakultas Ilmu Pendidikan-Universitas Negeri Malang-Jl. Semarang No. 5 Malang \\ E-mail: istiananurcahyani@yahoo.com
}

\begin{abstract}
This research purpose to know the effectiveness of relaxation technique in behavioral group counseling to reducing academic stress at senior high school students. Research use onegroup pretest-posttest design. The subject are selected 5 students based on high scores academic stress scale. Instruments used the scale academic stress was developed from various theories stress by Hans Selye (1976), Lazarus and Folkman (1984) with reliability is 0.898 and item validity $>0.3$. Data were analyzed using wilcoxon signed ranks test. The analysis showed the $\mathrm{Z}$ count value is -2.032 with significance level of $0.042<0.05$ which can be concluded that relaxation techniques effective for reducing academic stress of senior high school students.
\end{abstract}

Keywords: academic stress; behavioral group counseling; relaxation

\begin{abstract}
Abstrak: Penelitian ini bertujuan untuk menguji efektivitas teknik relaksasi dalam konseling kelompok behavioral untuk menurunkan stres belajar siswa SMA. Penelitian menggunakan one-group pretestposttest design. Subjek sebanyak 5 siswa yang dipilih berdasarkan skor tinggi skala stres belajar. Instrumen yang digunakan adalah skala stres belajar yang dikembangkan dari berbagai teori stres oleh Hans Selye (1976), Lazarus dan Folkman (1984) dengan reliabilitas 0.898 dan validitas per butir $>0.3$. Data dianalisis dengan uji beda wilcoxon signed ranks test. Hasil analisis menunjukkan nilai Z hitung $-2,032$ dengan taraf signifikansi $0.042<0.05$ yang dapat disimpulkan bahwa teknik relaksasi efektif untuk menurunkan stres belajar siswa SMA.
\end{abstract}

Kata kunci: stres belajar; konseling kelompok behavioral; relaksasi

Siswa kelas X di SMA Laboratorium Universitas Negeri Malang merupakan siswa baru atau peralihan dari tingkat sekolah menengah pertama. Dalam mengikuti kegiatan pembelajaran banyak tuntutan-tuntutan baru yang lebih ketat untuk dihadapinya. Tuntutan ini berupa tugas yang diberikan lebih banyak, tugas yang diberikan lebih sulit untuk dikerjakan, tuntutan terhadap materi yang harus dipelajari dari guru setiap mata pelajaran yang harus dipahami dengan cepat agar tidak tertinggal, adanya ulangan harian yang juga berpengaruh pada nilai akhir, mata pelajaran yang lebih sulit dari sebelumnya. Hal ini membuat siswa stres dan dapat memperlihatkan perilaku yang tidak tepat, sehingga dapat menghambat proses belajar dan mengajar. Fenomena tersebut terjadi saat peneliti melakukan kegiatan praktikum bimbingan dan konseling di sekolah.

Fenomena yang terjadi di SMA Laboratorium Universitas Negeri Malang adalah banyak siswa yang menunjukkan gejala-gejala stres. Ketika peneliti menjalani kegiatan praktikum bimbingan dan konseling di sekolah tersebut beberapa siswa mengalami pingsan saat pembelajaran berlangsung. Saat peneliti masuk 
untuk mengadakan bimbingan siswa menampakkan gejala stres berupa tegang, sukar berkonsentrasi, dan suka melamun. Hal ini menunjukkan adanya stres belajar yang dialami siswa.

Stres menurut Lazarus dan Folkman (1984) diartikan sebagai reaksi psikis dan psikologis terhadap tuntutan hidup yang membebani kehidupan seseorang yang akan menganggu kesejahteraan hidupnya dan menurut Hans Selye (1976) Stres merupakan suatu respons tubuh yang nonspesifik dari berbagai tuntutan. Tuntutan ini berdasarkan fenomena diatas dapat menyebabkan gejala stres yang dapat mengganggu kegiatan belajar siswa. Gejala tersebut dapat dilihat dengan adanya perubahan fisik dan psikis. Perubahan fisik, misalnya individu mengalami gemetar, tidak dapat tidur, berdebar-debar, gugup, keluar keringat, serta ciriciri lainnya. Sedangkan perubahan psikis yang berwujud secara emosi, intelektual, dan interpersonal. Gejala emosi antara lain marah-marah, mudah tersinggung, gejala intelektual antara lain mudah lupa, pikiran kacau, daya ingat menurun, sulit untuk berkonsentrasi dan gejala interpersonal antara lain kepercayaan pada orang lain menurun, dan senang mencari kesalahan orang lain.

Dari berbagai macam cara untuk menangani stres, salah satunya adalah mengaplikasikan teknik relaksasi. Teknik relaksasi merupakan salah satu penanganan psikologis yang membantu menurunkan kondisi keterangsangan tubuh yang ditimbulkan oleh stres. Stres menyebabkan respon atau reaksi tubuh yang berlebihan dan dapat menimbulkan masalah yang serius jika tidak ditangani.

Penelitian sebelumnya tentang manfaat relaksasi telah banyak dilakukan oleh para peneliti lain dengan berbagai metode, salah satunya relaksasi progressive (Edmund Jacobson, 1938) seorang dokter dari Universitas Chicago dan digunakan oleh (Joseph Wolpe dan Arnorld Lazarus, 1996) yang terbukti dapat mengurangi ketegangan yang terjadi karena adanya kontraksi otot pada saat stres.

Pada penelitian ini konseling kelompok behavioral dalam Corey (1999) merupakan proses belajar dalam kelompok yang bertujuan untuk menurunkan perilaku menyimpang yaitu stres belajar dengan menggunakan prosedur sistematis sehingga dapat terjadi perubahan khusus dalam perilaku subjek. Prosedur yang digunakan adalah assessment, goal setting, implementasi teknik dan evaluasi. Dalam konseling behavioral segala sesuatu yang terjadi pada manusia adalah hasil belajar dari proses interaksi dengan lingkungan dan manusia memiliki tugas untuk berkembang secara optimal. Tujuan konseling kelompok behavioral adalah untuk menurunkan stres belajar siswa dengan cara mengikuti proses belajar dan interaksi dalam kelompok.

Ketercapaian efektivitas teknik relaksasi yang diharapkan tidak lepas dari konsep behavioral yaitu dimana siswa mampu belajar pada proses konseling atau treatment yang diberikan untuk memperoleh perilaku yang tepat. Pada setiap pertemuan subjek diharapkan mendapatkan manfaat dari konseling yang dilakukan dengan evaluasi di akhir konseling. Dengan begitu akan diketahui perkembangan yang terjadi pada siswa atau perubahan-perubahan yang mengarah pada penurunan stres belajar.

Berdasarkan uraian tersebut, teknik relaksasi dapat menjadi salah satu cara untuk menurunkan stres belajar yang dialami oleh siswa dengan membuat rileks ketegangan yang disebabkan oleh gangguan fisik dan psikis yang merupakan reaksi tubuh terhadap stresor. Teknik relaksasi semakin populer sebagai metode pengajaran manusia untuk menanggulangi stres yang ditimbulkan oleh tuntutan berlebih dalam kehidupan sehari-hari. Untuk itu peneliti menguji cobakan teknik relaksasi dalam konseling kelompok behavioral guna menurunkan stres belajar siswa.

\section{METODE}

Penelitian ini menggunakan One-Group Pretest-Posttest Design. Pada penelitian ini pretest dilakukan dengan menggunakan skala stres belajar. Kemudian subjek memperoleh treatment teknik relaksasi dalam konseling kelompok behavioral selama 6 kali pertemuan. Setelah melaksanakan treatment subjek mengisi posttest untuk diketahui hasilnya apakah teknik relaksasi efektif dalam menurunkan stres belajar siswa.

Subjek eksperimen (subjek sasaran penelitian) yaitu 5 siswa yang teridentifikasi mempunyai frekuensi tingkat stres belajar yang sangat tinggi. Subjek ini adalah siswa kelas X SMA Laboratorium Universitas Negeri Malang tahun ajaran 2015/2016.

Pengumpulan data dilakukan dengan skala stres belajar. Tujuannya adalah untuk memperoleh gambaran tingkat tinggi rendah stres belajar siswa. Instrumen penelitian ini berupa skala stres belajar dan panduan konseling kelompok behavioral dengan teknik relaksasi autogenik. Proses penyusunan skala ini dikembangkan 
Tabel 1. Hasil Pretest dan Posttest Stres Belajar Siswa

\begin{tabular}{|c|c|c|}
\hline Nama & $\begin{array}{c}\text { Skor } \\
\text { Pretest }\end{array}$ & $\begin{array}{c}\text { Skor } \\
\text { Posttest }\end{array}$ \\
\hline $\mathrm{NE}$ & 148 & 83 \\
\hline $\mathrm{FI}$ & 125 & 64 \\
\hline SB & 117 & 71 \\
\hline$S R$ & 114 & 70 \\
\hline LF & 108 & 64 \\
\hline
\end{tabular}

Tabel 2. Hasil Skor Relaksasi Subjek

\begin{tabular}{lrrr}
\hline Nama & $\begin{array}{c}\text { Skor } \\
\text { Relaksasi } \\
\end{array}$ & $\begin{array}{c}\text { Skor } \\
\text { Relaksasi } \\
\text { 1 }\end{array}$ & $\begin{array}{c}\text { Skor } \\
\text { Relaksasi } \\
\text { NE }\end{array}$ \\
FI & 15 & 20 & 22 \\
SB & 15 & 22 & 22 \\
SR & 14 & 19 & 23 \\
LF & 12 & 16 & 20 \\
\hline
\end{tabular}

berdasarkan teori stres dalam Hans Selye (1976), Lazarus dan Folkman (1984). Sedangkan panduan konseling kelompok behavioral dengan teknik relaksasi diadaptasi dari buku Corey (1999).

Analisis data yang digunakan adalah stastistik deskriptif dan nonparametrik. Statistik deskriptif digunakan untuk memperoleh gambaran tentang tingkat stres belajar siswa. Teknik statistik nonparametrik yang digunakan untuk menguji hipotesis adalah uji beda wilcoxon sum-rank test. Uji wilcoxon digunakan untuk mencari perbedaan pretest dan posttest. Kaidah pengambilan keputusan adalah membandingkan nilai probabilitas dengan á sebesar 0.05. Jika probabilitas < á maka $\mathrm{H}_{0}$ ditolak, dan jika probabilitas > á maka $\mathrm{H}_{0}$ diterima.

\section{HASIL}

Pretest dilaksanakan di kelas X MIPA 3 dengan jumlah 5 siswa. Hasil secara rinci dapat dilihat pada tabel 1. Berdasarkan data pretest pada tabel 1, terdapat 5 siswa yang memiliki skor stres belajar tinggi. Pada pertemuan pertama dimulai dengan pembinaan hubungan baik. Hasil dari pertemuan pertama adalah subjek mulai terbuka dan berkeinginan memecahkan masalah yang dialami bersama-sama. Pertemuan kedua yaitu tahap assessment dan goal setting. Pada pertemuan ini peneliti bersama subjek membahas format Antecedent-Response-Consequense dan menganalisisnya. Setelah itu peneliti bersama subjek membuat keputusan untuk keluar dari masalah stres belajar. Hasil dari pertemuan kedua adalah subjek mampu memahami lebih dalam perilaku yang menyebabkan stres belajar, respon gejala stres belajar dan konsekuensi dari perilaku stres belajar serta subjek memiliki tujuan yang kuat untuk menurunkan respon gejala stres belajar. Pertemuan ketiga, keempat dan kelima adalah penggunaan teknik relaksasi. Hasil skor penggunaan teknik relaksasi dapat dilihat pada tabel 2.

Pada tabel 2 dapat dilihat bahwa perolehan skor tiap subjek mengalami peningkatan yang menunjukkan bahwa secara perlahan-lahan setiap subjek mampu mengikuti proses relaksasi dengan baik yang artinya subjek telah berhasil mengikuti konseling kelompok behavioral dengan teknik relaksasi untuk menurunkan stres belajar siswa. Pertemuan keenam adalah tahap evaluasi proses konseling. Peneliti bersama subjek sharing tentang apa yang dirasakan sebelum, saat, dan sesudah konseling. Hasil dari evaluasi adalah subjek 
dianggap sudah melakukan konseling kelompok dengan baik. Di akhir pertemuan peneliti memberikan motivasi kepada subjek untuk tetap melaksanakan relaksasi yang telah diajarkan sesuai dengan kebutuhan.

Setelah peneliti melaksanakan treatment, peneliti mengadakan posttest. Tujuan diadakannya posttest adalah untuk mengetahui penurunan skor stres belajar siswa setelah diberi treatment. Hasil penurunan skor stres belajar dapat dilihat pada tabel 1.

Berdasarkan tabel hasil pretest dan posttest dapat diketahui bahwa subjek mengalami perubahan skor setelah mengikuti konseling dengan menggunakan teknik relaksasi. Penjelasan tabel tersebut sebagai berikut: NE memperoleh skor stres belajar 148 yang tergolong tinggi. NE mengikuti konseling kelompok selama enam kali pertemuan. Pada pertemuan pertama NE adalah salah satu yang paling bersemangat untuk mengikuti konseling kelompok. NE selalu penasaran dan aktif bertanya terhadap proses konseling kelompok. Setiap masalah teman yang dibahas NE selalu ikut menanggapi. Skor posttest NE adalah 83, hal ini menunjukkan NE berhasil menurunkan stres yang dialami. FI merupakan subjek yang dari awal sampai akhir mengikuti konseling dengan memperhatikan teman-temannya berbicara mengemukakan masalahnya. Sekali dua kali FI menanyakan hal yang tidak dipahami saat konseling. FI dapat belajar dari pengalaman temannya sehingga skor posttest FI menunjukkan penurunan stres belajar dari skor 125 menjadi 64. SB merupakan subjek yang pendiam namun pada saat treatment subjek mulai terbuka dengan masalah sehingga subjek dapat perlahanlahan memahami diri untuk dapat menyelesaikan masalahnya. Subjek yang lain juga turut membantu dalam memahami SB hal ini dapat dilihat dari skor stres belajar SB yang semula 117 menjadi 71 . Sedangkan SR merupakan subjek yang keingintahuannya tinggi untuk melakukan konseling. Dari awal konseling SR memiliki motivasi dan selalu mengikuti konseling dengan baik. SR juga berhasil menurunkan stres belajarnya dari skor 114 menjadi 70. Subjek terakhir yang berinisial LF memiliki penurunan skor dari 108 menjadi 64. LF juga ikut berpartisipasi memberikan motivasi kepada teman-temannya. Oleh sebab itu LF juga dapat belajar dari apa yang disampaikan teman-temannya maupun peneliti. Seluruh subjek yang diberi treatment mengalami penurunan stres belajar, hal ini dikarenakan subjek mengikuti konseling dari awal sampai akhir dan dapat mengaplikasikan teknik relaksasi dengan baik.

Berdasarkan analisis deskriptif pada data kuantitatif dan kualitatif yang menunjukkan perbedaan skor stres belajar pada siswa yang tinggi menjadi rendah dan perubahan pada setiap pertemuan konseling menunjukkan teknik relaksasi efektif untuk menurunkan stres belajar siswa SMA. Pengujian hipotesis dilakukan untuk mengetahui keefektifan teknik relaksasi untuk mengurangi stres belajar siswa SMA. Dalam pengujian hipotesis digunakan skor pretest dan posttest dari subjek penelitian. Penggunaan relaksasi efektif untuk menurunkan stres belajar siswa SMA jika didapatkan skor posttest setelah pemberian treatment lebih rendah dari pretest. Selain itu hasil analisis menggunakan uji wilcoxon signed rank test sebagai berikut: Hasil uji wilcoxon menunjukkan nilai beda (z) -2.032 pada derajat signifikan asymp sig ( 2 tailed $)=0.042<0.05$, maka $\left(\mathrm{H}_{0}\right)$ ditolak dan $\left(\mathrm{H}_{1}\right)$ diterima. Dari hasil uji wilcoxon di atas dapat diartikan bahwa penggunaan teknik relakasi efektif untuk menurunkan stres belajar siswa.

\section{PEMBAHASAN}

Stres belajar adalah sebuah tingkah laku yang maladaptif karena apabila dibiarkan tingkah laku tersebut akan berdampak buruk kepada siswa seperti gangguan belajar. Dalam proses treatment, subjek diajak untuk menyadari konsekuensi dari stres belajar untuk membuat tujuan-tujuan baru. Selain itu subjek juga diajak untuk mengubah tingkah laku yang mengandung stres belajar menjadi tingkah laku yang lebih tepat. Hasil dari konseling kelompok behavioral adalah subjek perlahan-lahan mampu memahami diri sendiri dan dapat mengubah perilaku menjadi tepat. Hal ini sesuai dengan pandangan hakikat manusia dari teori behavioral bahwa tingkah laku manusia diperoleh dari hasil belajar dan proses terbentuknya kepribadian adalah melalui proses kematangan dalam belajar. Konseling behavioral diarahkan pada tujuan-tujuan memperoleh tingkah laku baru, penghapusan tingkah laku yang maladaptif, serta memperkuat tingkah laku yang diinginkan (Corey, 1988:200). Hal ini menunjukkan bahwa konseling kelompok behavioral efektif digunakan untuk menurunkan stres belajar siswa.

Dalam proses konseling peneliti menemukan bahwa stres yang tergolong tinggi yang dialami siswa berada di tahap perlawanan (resistance stage), dimana pertahanan terhadap stres menjadi semakin intensif, 
dan semua upaya dilakukan untuk melawan stres. Hal ini sesuai dengan teori Hans Selye (1976) yang disebut Sindrom Adaptasi Umum (General Adaptation Syndrome/GAS) yaitu konsep yang menggambarkan efek umum pada tubuh ketika tuntutan yang ditempatkan pada individu tersebut. GAS terdiri dari tiga tahap: peringatan (alarm reaction), perlawanan (resistance stage), kelelahan (exhausted). Dalam hal ini siswa sering mengalami gejala stres secara fisik, pikiran dan emosi namun upaya untuk menghilangkan sudah dilakukan namun tidak mencapai hasil. Sehingga siswa memerlukan bantuan untuk memecahkan masalah tersebut.

Adapun penyebab dari stres yang muncul adalah berbagai tuntutan yang dirasakan subjek sebagai seorang siswa sekolah menengah atas tingkat pertama. Banyaknya tugas yang diberikan dari guru membuat siswa tertekan secara fisik dan psikologis, dan juga orangtua yang menuntut siswa agar menjadi yang terbaik dalam segala hal serta hubungan teman sebaya yang masih belum begitu akrab. Hal ini juga disampaikan oleh Hardjana (1994:27) hal-hal yang dapat menjadi sumber stres antara lain tuntutan dari diri sendiri, keluarga dan lingkungan.

Menurut Lichstein (1988), manfaat dari relaksasi autogenik adalah membuat individu lebih mampu menghindari reaksi yang berlebihan karena adanya stres. Dari hasil pelaksanaan teknik relaksasi yang telah dilakukan dapat disimpulkan bahwa subjek memperoleh manfaat relaksasi yaitu menurunkan ketegangan yang terjadi akibat stres belajar yang dialami.

Didukung pula dengan penelitian terdahulu yang sejenis yang dilakukan oleh Mawar Wilanti (2011) dengan judul penelitian "Kemanjuran Relaksasi Otot dan Time Management untuk Menurunkan Stres Belajar Siswa Akselerasi di Asrama MAN Malang 1" menunjukkan bahwa relaksasi otot dan time management manjur untuk menurunkan stres belajar siswa kelas XI akselerasi di MAN Malang. Dengan demikian hasil penelitian ini juga cocok dengan hasil penelitian sebelumnya.

Pengujian hipotesis juga dilakukan dengan menggunakan skor pretest dan posttest dari subjek penelitian. Penerimaan hipotesis dalam penelitian dapat dibuktikan dari hasil analisis dari beda (z) -2.032 pada derajat signifikan $0.042(<0.05), \mathrm{H}_{0}$ ditolak karena dasar pengambilan keputusan adalah jika probabilitas error $<$ 0.05, maka $\mathrm{H}_{0}$ ditolak dan $\mathrm{H}_{1}$ diterima.

Penggunaan relaksasi merupakan teknik yang dapat digunakan konselor dalam menurunkan stres belajar siswa dengan memahami perilaku siswa serta mengubah perilaku siswa sesuai dengan tahap perkembangannya. Dari hasil penelitian dan perbandingan dengan penelitian sejenis terbukti bahwa teknik relaksasi dalam konseling kelompok behavioral merupakan sebuah teknik yang efektif untuk membantu siswa dalam menurunkan stres belajar siswa SMA.

\section{SIMPULAN DAN SARAN}

\section{Simpulan}

Berdasarkan hasil penelitian dan pembahasan, diperoleh perbedaan skor stres belajar siswa pada saat pretest dan posttest, sehingga dapat disimpulkan bahwa teknik relaksasi efektif untuk menurunkan stres belajar siswa. Relaksasi memberikan keadaan rileks sehingga siswa lebih bersemangat. Kefeektifan relaksasi juga tidak lepas dari tahapan-tahapan konseling kelompok behavioral yang diberikan karena siswa dapat mempelajari perilaku yang lebih tepat untuk mencegah adanya stres belajar serta saling bertukar pikiran untuk memecahkan masalah.

\section{Saran}

Berdasarkan hasil penelitian, maka peneliti memberikan saran bagi peneliti selanjutnya dan konselor sekolah. Saran berikut diantaranya: (1) Penggunaan relaksasi masih pada subjek terbatas sehingga masih banyak kelemahan dari hasil penelitian. Peneliti selanjutnya diharapkan dapat melakukan penelitian dengan subjek dalam skala besar. (2) Stres belajar siswa sangat banyak ditemui pada pelajar pada saat ini. Peneliti selanjutnya diharapkan dapat menggunakan variabel teknik relaksasi jenis yang lainnya. (3) Peneliti selanjutnya hendaknya melakukan follow up setelah posttest untuk mengetahui keajegan hasil penelitian. (4) Teknik 
relaksasi hendaknya digunakan konselor untuk menurunkan stres belajar siswa. (5) Konselor tidak terlibat langsung selama peneliti melakukan proses konseling, sehingga konselor hendaknya mendapatkan pelatihan penggunaan teknik relaksasi.

\section{DAFTAR RUJUKAN}

Corey, Gerald. 1988. Teori dan Praktek Konseling dan Psikoterapi. Bandung: PT Eresco.

Fauzan, Lutfi. 2009. Teknik Konseling Individu Relaksasi, (Online) (http://lutfifauzan.wordpress.com/ 2009/12/29/teknik-konseling-individu-relaksasi diakses April 2014).

Mangoenprasodjo, A. Setiono. 2005. Self Improvement For Your Stress, Kendarai Emosi \& Stres Menuju Puncak Prestasi Tertinggi. Yogyakarta: ThinkFresh.

Rahmawati, Hetti. 2008. Modifikasi perilaku. Malang: LP3 Universitas Negeri Malang

Santrock, John W. 2003. Adolescence $6^{\text {th }}$ ed. Jakarta: Erlangga.

Selye, Hans. 1976. The Stress of Life. New York: McGraw Hill.

Subagio, Adi. 2013. Terapi Relaksasi Autogenik, (Online) (http://adisubagio92.blogspot.co.id/2013/08/terapirelaksasi-autogenik.html diakses September 2015).

Sudjiwanati. 2008. Penanganan Stres, Kecemasan dan Depresi Pada Kasus Klinis. Malang: C.V Citra Malang.

Sugiyono. 2007. Metode Penelitian Pendidikan Pendekatan Kuantitatif, Kualitatif, dan R\&D. Bandung: Alfabeta.

Wilanti, Mawar. 2011. Kemanjuran Relaksasi Otot Dan Time Management Untuk Menurunkan Stres Belajar Siswa Akselerasi di Asrama MAN Malang 1. Skripsi tidak diterbitkan. Malang: Universitas Negeri Malang.

Wiramihardja, Sutardjo A. 2005. Pengantar Psikologi Abnormal. Bandung: Refika Aditama. 